\title{
Germination of spores of Clostridium difficile strains, including isolates from a hospital outbreak of Clostridium difficile-associated disease (CDAD)
}

\begin{abstract}
Correspondence
Mahfuzur R. Sarker

sarkerm@oregonstate.edu
\end{abstract}

Received 8 January 2008

Revised 21 April 2008

Accepted 8 May 2008

\author{
Daniel Paredes-Sabja, ${ }^{1} \dagger$ Colton Bond,${ }^{1} \dagger$ Robert J. Carman, ${ }^{2}$ Peter Setlow ${ }^{3}$ \\ and Mahfuzur R. Sarker ${ }^{1,4}$
}

\author{
${ }^{1}$ Department of Biomedical Sciences, Oregon State University, Corvallis, OR 97331, USA \\ ${ }^{2}$ TechLab, Inc., 2001 Kraft Drive, Blacksburg, VA 24060, USA \\ ${ }^{3}$ Department of Molecular, Microbial and Structural Biology, University of Connecticut Health \\ Center, Farmington, CT 06030, USA \\ ${ }^{4}$ Department of Microbiology, Oregon State University, Corvallis, OR 97331, USA
}

\section{INTRODUCTION}

Clostridium difficile is a Gram-positive, spore-forming, anaerobic bacterium, and is the causative agent of Clostridium difficile-associated disease (CDAD). Human CDAD is responsible for $25 \%$ of all cases of antibioticassociated diarrhoea (Bartlett, 1992), with approximately three million cases annually (Bean et al., 1990; Johnson et al., 1990; McFarland et al., 1989) and an estimated cost of $\$ 1.1$ billion in the USA (Kyne et al., 2002). CDAD generally occurs subsequent to a course of antibiotic treatment, which disrupts the normal colonic flora and allows the ingested $C$. difficile spores to germinate, outgrow and proliferate rapidly, filling empty niches (Kelly et al., 1994; Kelly \& LaMontt, 1998). During vegetative growth, C. difficile cells produce two major toxins, TcdA and $\mathrm{TcdB}$ (Borriello et al., 1990; Voth \& Ballard, 2005), which cause a

†These authors contributed equally to this work.

Abbreviations: CDAD, Clostridium difficile-associated disease; CLE, cortex-lytic enzyme; DPA, dipicolinic acid; Gl, gastrointestinal; PG, peptidoglycan. wide spectrum of nosocomial diseases, ranging from mild, self-limiting diarrhoea to serious and life-threatening pseudomembranous colitis and toxic megacolon (Borriello, 1998; Hurley \& Nguyen, 2002).

Spore germination has been well studied in Bacillus subtilis, and can be initiated by a variety of factors (termed germinants), including nutrients, cationic surfactants such as dodecylamine, enzymes, hydrostatic pressure and a $1: 1$ chelate of $\mathrm{Ca}^{2+}$ and pyridine-2,6-dicarboxylic acid (dipicolinic acid; DPA) (Paidhungat \& Setlow, 2000; Paidhungat et al., 2002). Nutrient germinants for spores of Bacillus species include L-alanine, D-glucose, inosine and a mixture of L-asparagine, D-glucose, $\mathrm{D}$-fructose and $\mathrm{K}^{+}$ ions (AGFK) (Clements \& Moir, 1998; Moir et al., 2002; Setlow, 2003). The receptors that sense nutrient germinants are located in the spore inner membrane, and nutrient germinant receptor-ligand binding stimulates the release of monovalent cations $\left(\mathrm{H}^{+}, \mathrm{Na}^{+}\right.$and $\left.\mathrm{K}^{+}\right)$, divalent cations $\left(\mathrm{Ca}^{2+}, \mathrm{Mg}^{2+}\right.$ and $\left.\mathrm{Mn}^{2+}\right)$, and the spore large depot ( $\sim 20 \%$ of core dry weight) of DPA (Setlow, 2003). DPA is 
released in exchange for some water as a $1: 1$ chelate with divalent cations, predominantly $\mathrm{Ca}^{2+}(\mathrm{Ca}-\mathrm{DPA})$, and $\mathrm{Ca}-$ DPA release triggers downstream events in spore germination. Most important among the latter is the hydrolysis of the spore peptidoglycan (PG) cortex by one or more cortex-lytic enzymes (CLEs), which allows the core to expand and take up even more water, thus reaching the hydration levels found in growing cells. The latter event restores protein movement and enzyme action in the spore core, and leads to the resumption of energy metabolism and macromolecular synthesis (Cowan et al., 2003; Setlow, 2006). Spore germination in Clostridium species is less well studied than in B. subtilis. Limited studies have shown that spores of Clostridium botulinum, Clostridium sporogenes and Clostridium perfringens germinate in response to certain amino acids and salts (Ando, 1974; Broussolle et al., 2002; Paredes-Sabja et al., 2008c). Spores of $C$. difficile strains also germinate in nutrient media with bile salts, and glycine and bile salts have recently been reported to be cogerminants (Sorg \& Sonenshein, 2008; Wilson et al., 1982; Wilson, 1983). However, the precise mechanism of action of germinants in spores of this species is unclear, since genes for nutrient germinant receptors appear to be absent from the C. difficile genome (Sebaihia et al., 2006).

In this study, we have investigated the germination of spores of $C$. difficile, including some clinical isolates obtained from a CDAD outbreak (CDAD isolates) (McEllistrem et al., 2005). Major findings on these $C$. difficile spores were that: (1) they germinated well with a complex nutrient-rich medium, but not with individual nutrients; (2) their germination was not accelerated significantly by bile salts; (3) they germinated well with $\mathrm{KCl}$ or inorganic phosphate $\left(\mathrm{P}_{\mathrm{i}}\right)$; and $(4)$ they germinated well with both $\mathrm{Ca}-\mathrm{DPA}$ and the cationic surfactant dodecylamine.

\section{METHODS}

Bacterial strains. The laboratory C. difficile strain JIR8094, an erythromycin-sensitive derivative of strain 630, the genome of which has been sequenced (O'Connor et al., 2006), and five CDAD isolates (Pitt33, Pitt40, Pitt221, Pitt251 and Pitt301; McEllistrem et al., 2005) were used in this work.

Spore preparation. Starter C. difficile cultures $(10 \mathrm{ml})$ were prepared by overnight growth at $37{ }^{\circ} \mathrm{C}$ in TGY-vegetative medium (3\% tryptic soy broth, $2 \%$ glucose, $1 \%$ yeast extract, $0.1 \%$ Lcysteine). To prepare $C$. difficile spores, we first compared sporulation of $C$. difficile strain JIR8094 in a sporulation medium (SM) used earlier for C. difficile sporulation (Wilson et al., 1982) versus DuncanStrong (DS) medium, a sporulation medium used routinely for $C$. perfringens (Duncan \& Strong, 1968; Kokai-Kun et al., 1994). Sporulating cultures were prepared by inoculating $0.6 \mathrm{ml}$ TGY starter culture into $10 \mathrm{ml}$ of each medium, followed by incubation for $24 \mathrm{~h}$ at $37^{\circ} \mathrm{C}$. Since similar levels of sporulation of $\mathrm{C}$. difficile were observed $\left(\sim 10^{7}\right.$ spores $\left.\mathrm{ml}^{-1}\right)$ in both SM and DS media (data not shown), C. difficile spores were routinely prepared using DS medium.

For spore purification, spore suspensions were prepared in $600 \mathrm{ml}$ DS medium. Spores were cleaned of debris by repeated centrifugation and washing with sterile distilled water, and were resuspended in distilled water at $\mathrm{OD}_{600} \sim 6$ and stored at $-20{ }^{\circ} \mathrm{C}$ until use (ParedesSabja et al., 2008c). All spore preparations used in this work were $>99 \%$ free of sporulating cells, cell debris and germinated spores, as determined by phase-contrast microscopy.

Assessment of colony-forming efficiency of spores. To assess the colony-forming efficiency of $C$. difficile spores, spore suspensions at an $\mathrm{OD}_{600}$ of 1 were heat activated at $80{ }^{\circ} \mathrm{C}$ for $10 \mathrm{~min}$, aliquots of dilutions were plated on Brain Heart Infusion (BHI) agar, the plates were incubated at $37^{\circ} \mathrm{C}$ anaerobically for $24 \mathrm{~h}$, and colonies were counted to determine c.f.u. $\mathrm{ml}^{-1}$. The number of spores per $\mathrm{ml}$ was counted directly by phase-contrast microscopy using a counting chamber (Model Z30000, Weber Scientific), and the percentage of spores that gave rise to colonies on BHI agar was calculated as [c.f.u. $\left.\left(\mathrm{OD}_{600} \text { unit }\right)^{-1} \mathrm{ml}^{-1}\right] /\left[\right.$ spore count $\left.\left(\mathrm{OD}_{600} \text { unit }\right)^{-1} \mathrm{ml}^{-1}\right] \times 100 \%$.

Spore germination. Preliminary experiments indicated that $C$. difficile spore germination was more efficient when spores were heat activated at $80{ }^{\circ} \mathrm{C}$ for $10 \mathrm{~min}$ rather than at 60,70 or $90{ }^{\circ} \mathrm{C}$ (data not shown), as is also the case for C. perfringens spores (Paredes-Sabja et al., 2008c). Consequently, all germination experiments used heatactivated spores unless noted otherwise. After heat activation, spores were cooled to room temperature, sonicated briefly to break up any clumps and incubated at $40{ }^{\circ} \mathrm{C}$ for $10 \mathrm{~min}$ before addition of germinants, and the $\mathrm{OD}_{600}$ of the spore suspensions was measured to assess spore germination (Smartspec 3000 Spectrophotometer, BioRad Laboratories); levels of spore germination were also confirmed by phase-contrast microscopy.

Germination in nutrient medium was performed in BHI broth. Germination with bile salts and/or glycine was carried out in $10 \mathrm{mM}$ $\mathrm{Na}_{2} \mathrm{HPO}_{4}$ buffer ( $\mathrm{pH}$ 7.5) to reduce the background germination caused by $\mathrm{P}_{\mathrm{i}}$ (see below). Germination was routinely carried out aerobically, since no difference in germination kinetics was detected under anaerobic conditions (data not shown), and was in $25 \mathrm{mM}$ sodium phosphate buffer ( $\mathrm{pH}$ 7.5) unless noted otherwise. Spore germination kinetics exhibited no significant difference when assessed at 37 or $40{ }^{\circ} \mathrm{C}$ (data not shown). Thus, to allow direct comparison with previous studies of germination of $C$. perfringens spores (Paredes-Sabja et al., 2008b, c), spore germination of C. difficile was carried at $40{ }^{\circ} \mathrm{C}$. No noticeable spore clumping was observed during germination assays. The extent of spore germination was determined by measuring the decrease in $\mathrm{OD}_{600}$ of germinating spore suspensions, and was expressed as a percentage of the initial $\mathrm{OD}_{600}$. Since a decrease in $\mathrm{OD}_{600}$ of $\sim 65 \%$ corresponds to $\geqslant 99 \%$ spore germination as assessed by phase-contrast microscopy, the percentage decrease in the $\mathrm{OD}_{600}$ was converted to the percentage germination by taking an $\mathrm{OD}_{600}$ decrease of $65 \%$ as $100 \%$ germination. The rate of germination was expressed as the maximum rate of loss of $\mathrm{OD}_{600}$ of spore suspensions relative to initial values. To evaluate effects of $\mathrm{pH}$ on spore germination rates, germination was performed in $25 \mathrm{mM}$ sodium citrate buffer ( $\mathrm{pH} 2$ and 4), $25 \mathrm{mM}$ sodium phosphate buffer ( $\mathrm{pH} 2,5$ and 7.5 ) or $25 \mathrm{mM}$ Tris/HCl buffer $(\mathrm{pH} 8.5)$ at $40{ }^{\circ} \mathrm{C}$. All values reported are averages of two experiments performed with two independent spore preparations, and individual values varied by $\leqslant 15 \%$ from the average.

For germination with dodecylamine, spores at $\mathrm{OD}_{600} \sim 1$ were used without heat activation, since this had no effect on germination with this agent, as has been found for spores of other species (ParedesSabja et al., 2008c). Spores were incubated at $60{ }^{\circ} \mathrm{C}$ with $1 \mathrm{mM}$ dodecylamine in $25 \mathrm{mM}$ Tris/HCl buffer ( $\mathrm{pH} 7.4)$. Aliquots ( $1 \mathrm{ml})$ of germinating cultures were centrifuged at $16110 \mathrm{~g}$ for $2 \mathrm{~min}$ in a microcentrifuge, and DPA in the supernatant fluid was measured by monitoring $\mathrm{OD}_{270}$. The total $\mathrm{OD}_{270}$ that could be released from these spores was determined by boiling a sample of dormant spores at an $\mathrm{OD}_{600}$ of 1 for $60 \mathrm{~min}$, followed by cooling on ice, centrifugation and 
measurement of the $\mathrm{OD}_{270}$ of the supernatant fluid as described previously (Cabrera-Martinez et al., 2003; Setlow et al., 2003). All experiments with dodecylamine were repeated at least twice, and results for different experiments differed by $\leqslant 5 \%$.

For germination with Ca-DPA, spores were germinated with or without prior heat activation, cooled to room temperature, diluted to $\mathrm{OD}_{600} \sim 1.5$ and incubated at $40{ }^{\circ} \mathrm{C}$ with $\mathrm{Ca}-\mathrm{DPA}(50 \mathrm{mM} \mathrm{CaCl}$, $50 \mathrm{mM}$ DPA adjusted to $\mathrm{pH} 8.0$ with Tris/HCl), as described previously (Paredes-Sabja et al., 2008c). At various times, $1 \mathrm{ml}$ aliquots were centrifuged for $2 \mathrm{~min}$ in a microcentrifuge, and the spore pellet was washed four times with sterile distilled water and suspended in $1 \mathrm{ml}$ sterile water. Residual spore core DPA content was determined by boiling samples for $60 \mathrm{~min}$, centrifuging them for $5 \mathrm{~min}$, and measuring the $\mathrm{OD}_{270}$ of the supernatant fluid as described previously (Cabrera-Martinez et al., 2003; Setlow et al., 2003). The change in the $\mathrm{OD}_{600}$ of spore cultures during germination with $\mathrm{Ca}-$ DPA was also measured as described above. All experiments with $\mathrm{Ca}-$ DPA were repeated at least twice, and results for different experiments differed by $\leqslant 5 \%$.

Measurement of spore core DPA content. Spore DPA content was measured by boiling $1 \mathrm{ml}$ spores at $\mathrm{OD}_{600} 6$ for $60 \mathrm{~min}$, followed by cooling on ice, centrifuging at $16110 \mathrm{~g}$ for $5 \mathrm{~min}$, and assaying DPA in the supernatant fluid chemically as described elsewhere (Rotman \& Fields, 1968).

\section{RESULTS}

\section{Nutrient germination of $\boldsymbol{C}$. difficile spores}

Spore germination is essential for $C$. difficile spores to cause disease, but the specific requirements for $C$. difficile spore germination are relatively poorly defined. As expected (Wilson et al., 1982; Wilson, 1983), spores of the six C. difficile strains gave colonies on a complex nutrient medium, BHI (Table 1). Although there was significant variability in the colony-forming efficiency among spores of the different isolates, heat activation increased spore titres significantly (Table 1 ) and the titres were generally similar to those observed previously with $C$. perfringens spores (Paredes-Sabja et al., 2008c), except for spores of $C$. difficile Pitt221 (Table 1). A relatively high level of germination was also observed for the spores of all six $C$. difficile strains after $60 \mathrm{~min}$ incubation in BHI broth (Table 1, Fig. 1a), although which of the individual components of BHI broth triggers $C$. difficile spore germination is not clear. These results are different from those obtained in a recent study, in which spores of two other C. difficile strains, CD196 and UK14, germinated poorly in BHI broth (Sorg \& Sonenshein, 2008). However, a significant difference between the current work and the study of Sorg \& Sonenshein (2008) is that the heatactivation temperature was $80{ }^{\circ} \mathrm{C}$ for $10 \mathrm{~min}$ in the current work versus $60{ }^{\circ} \mathrm{C}$ for $20 \mathrm{~min}$ in the other study. Indeed, the $C$. difficile spores germinated to a significantly lesser extent when heat activated at $60{ }^{\circ} \mathrm{C}$ for 20 min compared with spores that were heat activated at $80{ }^{\circ} \mathrm{C}$ for $10 \mathrm{~min}$ (Fig. 1a; data not shown).

The study of Sorg \& Sonenshein (2008) also reported that bile salts and glycine act as co-germinants to give a significant increase in the germination of $C$. difficile spores. To test if this is also the case for spores of the six isolates used in the current work, purified spores were incubated in BHI broth with bile salts. However, the bile salts actually reduced the germination of spores of the six $C$. difficile isolates in BHI broth, irrespective of heat-activation conditions (Table 1, Fig. 1b). In addition, no significant differences were seen in the germination of the spores of the six $C$. difficile strains that were heat activated at $60{ }^{\circ} \mathrm{C}$

Table 1. Colony-formation efficiency and germination of $C$. difficile spores in rich medium

\begin{tabular}{|c|c|c|c|c|c|c|c|}
\hline \multirow[t]{3}{*}{ Strain } & \multicolumn{4}{|c|}{ Colony-forming efficiency } & \multicolumn{3}{|c|}{$\begin{array}{c}\text { Average percentage } \\
\text { germination }{ }^{\star} \text { within } 60 \mathrm{~min} \text { in: }\end{array}$} \\
\hline & \multirow{2}{*}{$\begin{array}{l}\text { Spores }\left(\mathrm{OD}_{600}\right. \\
\text { unit })^{-1} \mathrm{ml}^{-1}\end{array}$} & \multicolumn{2}{|c|}{ c.f.u. $\left(\mathrm{OD}_{600} \text { unit }\right)^{-1} \mathrm{ml}^{-1} \dagger$} & \multirow[t]{2}{*}{ Efficiency $(\%) \ddagger$} & \multirow[t]{2}{*}{ BHI } & \multirow[t]{2}{*}{ BSC $\$$} & \multirow[t]{2}{*}{ BST $\S$} \\
\hline & & No HA & HA & & & & \\
\hline JIR8094 & $4.8 \times 10^{7}$ & $3.4 \times 10^{6}$ & $1.3 \times 10^{7}$ & 26 & 47 & 12 & 15 \\
\hline Pitt40 & $5.1 \times 10^{7}$ & $2.2 \times 10^{6}$ & $7.8 \times 10^{6}$ & 14 & 32 & 15 & 17 \\
\hline Pitt221 & $1.2 \times 10^{8}$ & $2.0 \times 10^{6}$ & $4.7 \times 10^{6}$ & 4 & 12 & 9 & 9 \\
\hline Pitt251 & $4.7 \times 10^{7}$ & $2.6 \times 10^{6}$ & $2.3 \times 10^{7}$ & 47 & 63 & 9 & 12 \\
\hline Pitt301 & $8.7 \times 10^{7}$ & $3.4 \times 10^{6}$ & $1.2 \times 10^{7}$ & 14 & 49 & 16 & 19 \\
\hline
\end{tabular}

${ }^{*}$ Spores were heat activated $\left(80{ }^{\circ} \mathrm{C}, 10 \mathrm{~min}\right)$ and incubated at $40{ }^{\circ} \mathrm{C}$ for $60 \mathrm{~min}$ in BHI broth with or without bile salts. The OD ${ }_{600}$ of germinating cultures was measured, expressed as the percentage germination as described in Methods and the approximate degree of spore germination was confirmed by phase-contrast microscopy. Results are averages of duplicate experiments, and the variance in all cases was less than $8 \%$.

$\dagger$ Spores were counted microscopically, plated on BHI agar before (No HA) and after (HA) heat activation at $80{ }^{\circ} \mathrm{C}$ for 10 min and incubated at $37^{\circ} \mathrm{C}$ overnight, and colonies were counted as described in Methods.

\$Efficiency was determined using heat-activated spore suspensions and calculated as: [c.f.u. $\left.\left(\mathrm{OD}_{600} \mathrm{unit}^{-1}\right) \mathrm{ml}^{-1}\right] /\left[\mathrm{spore}^{\mathrm{count}}\left(\mathrm{OD}_{600} \text { unit }\right)^{-1}\right.$ $\left.\mathrm{ml}^{-1}\right] \times 100 \%$; experiments were repeated at least twice and the variation was $\leqslant 30 \%$.

$\S$ BHI broth supplemented with $1 \%$ sodium cholate (BSC) or sodium taurocholate (BST). 
(a)

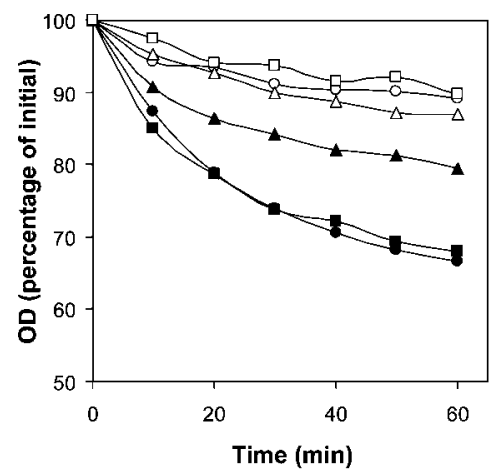

(b)

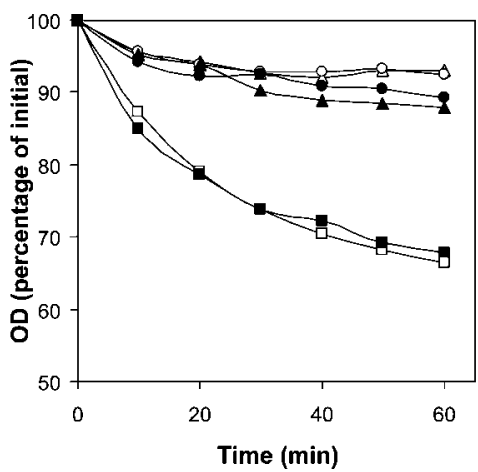

(c)

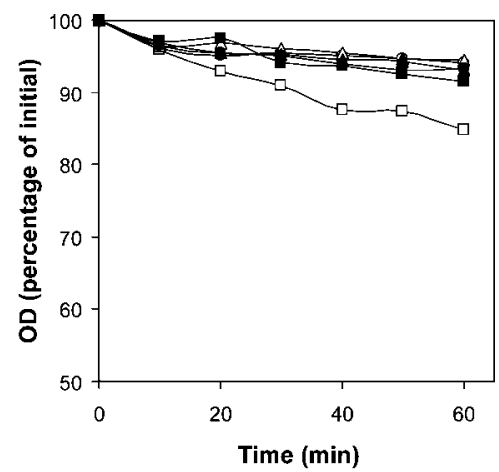

Fig. 1. Effect of activation temperature and bile salts on C. difficile spore germination with nutrients. (a) Spores of strains JIR8094 (circles), Pitt40 (triangles) and Pitt 301 (squares) were heat activated at $80{ }^{\circ} \mathrm{C}$ for $10 \mathrm{~min}$ (filled symbols) or at $60{ }^{\circ} \mathrm{C}$ for 20 min (open symbols), and germinated in BHI broth at $40{ }^{\circ} \mathrm{C}$. (b) Spores of strains JIR8094 (open symbols) and Pitt301 (filled symbols) were activated at $80^{\circ} \mathrm{C}$ for $10 \mathrm{~min}$ and germinated in: $\mathrm{BHI}$ broth (squares); $\mathrm{BHI}$ broth plus $1 \%$ sodium cholate (circles); and BHI broth plus $1 \%$ sodium taurocholate (triangles). (c) Spores of strains JIR8094 (open symbols) and Pitt301 (filled symbols) were heat activated at $80{ }^{\circ} \mathrm{C}$ for $10 \mathrm{~min}$ and germinated in: $1.3 \mathrm{mM}$ glycine in $10 \mathrm{mM}$ sodium phosphate buffer (pH 7.5) (squares); $1.3 \mathrm{mM}$ glycine in $10 \mathrm{mM}$ sodium phosphate buffer ( $\mathrm{pH} 7.5$ ) plus $1 \%$ sodium cholate (circles); and $1.3 \mathrm{mM}$ glycine in $10 \mathrm{mM}$ sodium phosphate buffer $(\mathrm{pH} 7.5)$ plus $1 \%$ sodium taurocholate (triangles). Spore germination was measured by monitoring the $\mathrm{OD}_{600}$ of germinating cultures as described in Methods. In all cases the approximate degree of spore germination was confirmed by phase-contrast microscopy.

for $20 \mathrm{~min}$ and incubated with glycine or bile salts alone or with glycine plus bile salts (data not shown). Indeed, the germination of these spores was similar to that of the spores in buffer $(10 \mathrm{mM}$ sodium phosphate buffer, $\mathrm{pH} 7.5)$ alone, as $\leqslant 10 \%$ of spores became phase dark after $60 \mathrm{~min}$ incubation at $40{ }^{\circ} \mathrm{C}$. Heat activation at $80{ }^{\circ} \mathrm{C}$ for $10 \mathrm{~min}$ enhanced germination of the spores of these strains with glycine plus bile salts, but only to a small extent, and the germination of JIR8094 and Pitt301 spores with glycine with or without bile salts was significantly less than that obtained in BHI broth (Table 1, Fig. 1a, c).
While combinations of bile salts and glycine seemed to have no major effect on germination of $C$. difficile spores, individual amino acids and some salts can induce germination of spores of many Bacillus and Clostridium species (Broussolle et al., 2002; Clements \& Moir, 1998; Paredes-Sabja et al., 2008c; Rode \& Foster, 1962). Consequently, a number of individual components of BHI broth, in particular free amino acids, were tested to identify the specific germinant(s) that trigger $C$. difficile spore germination. However, none of the 20 tested amino acids induced germination of spores of the six C. difficile

Table 2. Germination of C. difficile spores in the presence of amino acids and salts

All experiments were performed in $25 \mathrm{mM}$ sodium phosphate buffer ( $\mathrm{pH}$ 7.5), with or without $100 \mathrm{mM}$ germinant. Spores were heat activated $\left(80{ }^{\circ} \mathrm{C}, 10 \mathrm{~min}\right.$ ) and incubated at $40{ }^{\circ} \mathrm{C}$ for $60 \mathrm{~min}$; the $\mathrm{OD}_{600}$ of the germinating cultures was measured and expressed as the percentage germination as described in Methods, and the approximate degree of spore germination was confirmed by phase-contrast microscopy. Results are the means of duplicate experiments, and the variance in all cases was less than $10 \%$ of the mean.

\begin{tabular}{|c|c|c|c|c|c|c|c|c|c|c|c|}
\hline \multirow[t]{2}{*}{ Strain } & \multicolumn{11}{|c|}{ Mean percentage germination in $60 \mathrm{~min}$ with: } \\
\hline & $\mathrm{H}_{2} \mathrm{O}$ & Phosphate $^{*}$ & Ala & Ser & Asn & $\mathrm{AK} \dagger$ & $\mathrm{KCl}$ & $\mathrm{NaCl}$ & $\mathrm{KPO}_{4} \ddagger$ & KI & $\mathrm{KBr}$ \\
\hline JIR8094 & 0 & 22 & 12 & 17 & 17 & 63 & 82 & 25 & 77 & 43 & 45 \\
\hline Pitt33 & 5 & 9 & 12 & 14 & 12 & 80 & 92 & 20 & 60 & 29 & 75 \\
\hline Pitt40 & 0 & 18 & 22 & 22 & 22 & 37 & 54 & 17 & 35 & 26 & 29 \\
\hline Pitt221 & 3 & 9 & 8 & 9 & 8 & 18 & 31 & 18 & 14 & 9 & 11 \\
\hline Pitt251 & 0 & 14 & 11 & 11 & 12 & 100 & 82 & 20 & 15 & 42 & 52 \\
\hline Pitt301 & 2 & 28 & 31 & 37 & 34 & 71 & 80 & 26 & 57 & 40 & 65 \\
\hline
\end{tabular}

*Phosphate: $25 \mathrm{mM}$ sodium phosphate buffer, $\mathrm{pH} 7.5$, only.

$\dagger \mathrm{AK}$ is a mixture of $100 \mathrm{mM} \mathrm{L}$-asparagine and $100 \mathrm{mM} \mathrm{KCl}$.

$\ddagger \mathrm{KPO}_{4}$ was at $100 \mathrm{mM}(\mathrm{pH} 7.5)$ and without the sodium phosphate. 
strains (Table 2; data not shown). Indeed, germination with these amino acids was similar to that with phosphate buffer alone when germination was assessed either by the decrease in $\mathrm{OD}_{600}$ of germinating cultures or by phasecontrast microscopy (Table 2). Interestingly, phosphate buffer also triggered the germination of a small but significant percentage of $C$. difficile spores after $60 \mathrm{~min}$ of incubation, with $5-20 \%$ of the spores becoming phase dark (Table 2; data not shown). As found with spores of $C$. perfringens (Paredes-Sabja et al., 2008c), C. difficile spores did germinate in $\mathrm{AK}$ (a mixture of $100 \mathrm{mM}$ asparagine plus $100 \mathrm{mM} \mathrm{KCl}$ ) (Table 2). However, much of the effect of $\mathrm{AK}$ appeared to be due to the $\mathrm{KCl}$, as $\mathrm{KCl}$ alone gave significant germination of spores of all $C$. difficile isolates, while asparagine alone was ineffective (Table 2). In contrast to the stimulation of $C$. difficile spore germination by $\mathrm{KCl}$, $\mathrm{NaCl}$ was ineffective (Table 2). Other potassium salts stimulated spore germination, but not as well as $\mathrm{KCl}$; the general order of effectiveness was $\mathrm{KCl}>\mathrm{KBr} \approx \mathrm{KH}_{2} \mathrm{PO}_{4}$
$>$ KI (Table 2). Previous work has shown that spores of $C$. perfringens (Paredes-Sabja et al., 2008c) and Bacillus megaterium QM B1551 (Christie \& Lowe, 2007; Rode \& Foster, 1962) are also germinated by salts, in particular $\mathrm{K}^{+}$ salts, alone.

The $\mathrm{pH}$-dependence of $\mathrm{KCl}$-induced germination of spores of two representative $C$. difficile strains (JIR8094 and Pitt301) was similar, with a $\mathrm{pH}$ optimum of 6.0-7.5 (Fig. 2a). The rate of $\mathrm{KCl}$-induced germination of JIR8094 and Pitt301 spores was dependent on the $\mathrm{KCl}$ concentration, with a maximum germination response at 100$200 \mathrm{mM}$ (Fig. 2b). While JIR8094 spores incubated with $100 \mathrm{mM} \mathrm{KCl}$ exhibited a constant rate of germination for $\sim 60 \mathrm{~min}$ (Fig. 2c), Pitt301 spores incubated similarly germinated much more rapidly, and almost completely within the first $10 \mathrm{~min}$ of incubation (Fig. 2c), with $\geqslant 99 \%$ of the spores from both isolates becoming phase dark after 60 min incubation (data not shown). (a)

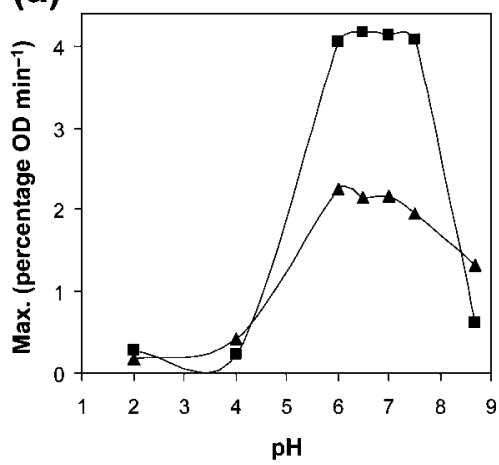

(d)

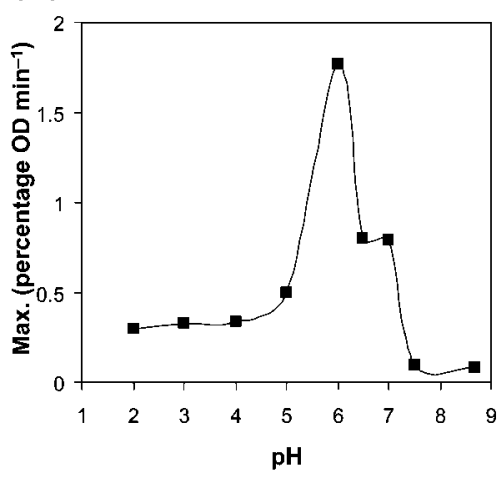

(b)

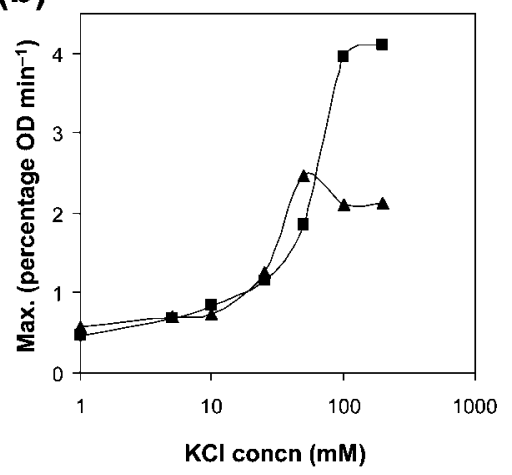

(e)

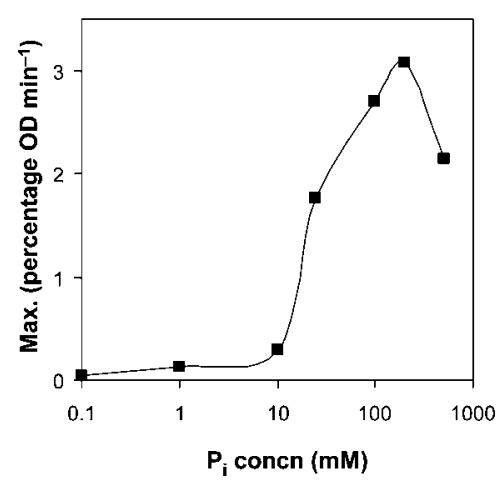

(c)

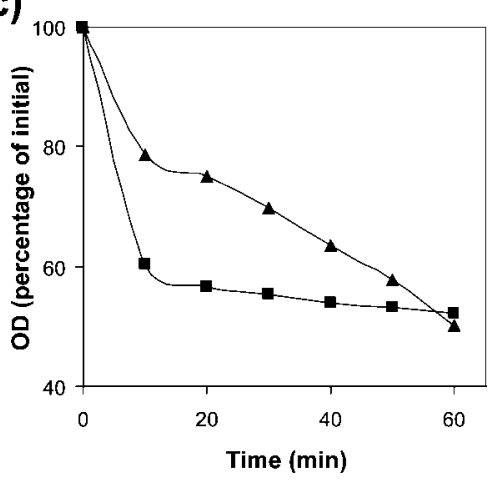

(f)

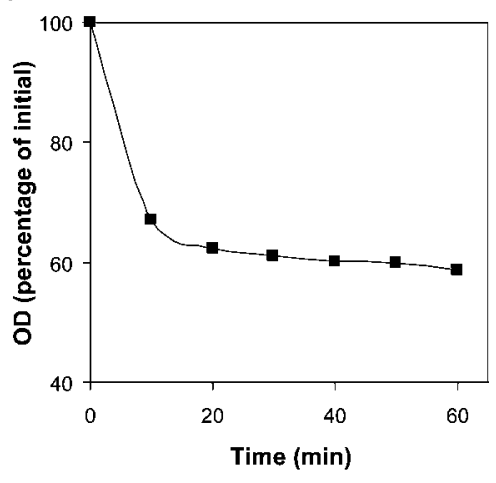

Fig. 2. Effect of $\mathrm{pH}, \mathrm{KCl}$ and $\mathrm{P}_{\mathrm{i}}$ on the rate of germination of $C$. difficile spores. Spores of strains JIR8094 ((A) and Pitt301 ( were heat activated at $80{ }^{\circ} \mathrm{C}$ for $10 \mathrm{~min}$ and germinated at $40{ }^{\circ} \mathrm{C}$ in: (a) $100 \mathrm{mM} \mathrm{KCl}$ in $25 \mathrm{mM}$ sodium phosphate buffer at various $\mathrm{pH}$ values; (b) various concentrations of $\mathrm{KCl}$ in $25 \mathrm{mM}$ sodium phosphate buffer, $\mathrm{pH}$ 7.0; (c) $100 \mathrm{mM} \mathrm{KCl}$ in $25 \mathrm{mM}$ sodium phosphate buffer, $\mathrm{pH}$ 7.0. Heat-activated spores of strain Pitt301 were incubated at $40{ }^{\circ} \mathrm{C}$ in: (d) $25 \mathrm{mM}$ sodium phosphate buffer at various $\mathrm{pH}$ values; (e) various concentrations of sodium phosphate buffer, $\mathrm{pH} 6.0$; and (f) $200 \mathrm{mM}$ sodium phosphate buffer, $\mathrm{pH}$ 6.0. Spore germination was measured by monitoring the $\mathrm{OD}_{600}$ of germinating cultures and either the maximum rate (Max.) was determined over $60 \min (a, b, d, e)$ or germination was monitored continuously (c, $f$ ), as described in Methods. In all cases the approximate degree of spore germination was confirmed by phase-contrast microscopy. 


\section{Effect of $P_{i}$ on C. difficile spore germination}

Interestingly, during the study of the $\mathrm{pH}$ optimum of $\mathrm{KCl}$ induced germination (Fig. 2a), we noticed that Pitt301 and JIR8094 spores germinated with $25 \mathrm{mM}$ sodium phosphate at $\mathrm{pH} 6.0$ alone. This led us to hypothesize that $\mathrm{P}_{\mathrm{i}}$ might also induce germination of spores of $C$. difficile isolates. To test this, we examined the germination of spores of the six C. difficile strains in $25 \mathrm{mM}$ sodium phosphate at $\mathrm{pH}$ values from 3 to 7.5. The highest extent of germination of spores of the surveyed isolates was obtained with sodium phosphate at $\mathrm{pH} 6.0$, although this was lower than that obtained with $\mathrm{KCl}$ plus sodium phosphate (Tables 2 and 3 ). To determine whether it was the Pi or the $\mathrm{pH}$ of 6.0 that was inducing $C$. difficile spore germination, we also carried out germination using citrate and MOPS buffers. Germination in these buffers at pH 6.0 or 7.0 was greater than in water alone but lower than in sodium phosphate at $\mathrm{pH}$ 6.0, and these results were confirmed by phase-contrast microscopy (Table 3 ). The latter results strongly suggest that $\mathrm{P}_{\mathrm{i}}$ is a significant factor in inducing $C$. difficile spore germination. The optimum $\mathrm{pH}$ for germination with $25 \mathrm{mM}$ sodium phosphate of spores of a fast-germinating isolate (Pitt301) was 6.0 (Fig. 2d), and the rate of $\mathrm{P}_{\mathrm{i}^{-}}$ induced germination of these spores was maximal at $\sim 200 \mathrm{mM} \mathrm{P} \mathrm{P}_{\mathrm{i}}$ (Fig. 2e). Pitt301 spores incubated with $200 \mathrm{mM} \mathrm{P}_{\mathrm{i}}$ at $\mathrm{pH} 6.0$ exhibited a high level of germination after $10 \mathrm{~min}$ of incubation, as was observed with $\mathrm{KCl}$ (Fig. 2c, f). These results further indicate that $\mathrm{P}_{\mathrm{i}}$ at $\mathrm{pH} 6.0$ is capable of inducing germination of $C$. difficile spores relatively efficiently.

\section{Dodecylamine germination of $\boldsymbol{C}$. difficile spores}

Dodecylamine, a cationic surfactant, can also germinate spores of many Bacillus and Clostridium species (Setlow et al., 2003). In B. subtilis spores, dodecylamine may act by opening a channel in the spore inner membrane allowing DPA release (Setlow et al., 2003; Vepachedu \& Setlow,
2005, 2007). Levels of DPA in spores of $C$. difficile JIR8094 and Pitt301 were $17.3 \pm 1.6$ and $18 \pm 0.6 \mu \mathrm{g}$ DPA $\left(\mathrm{OD}_{600}\right.$ unit $)^{-1} \mathrm{ml}^{-1}$, respectively, values similar to those for $B$. subtilis (Paidhungat et al., 2000) and C. perfringens (Paredes-Sabja et al., 2008a, b) spores. Incubation of JIR8094 and Pitt301 spores with dodecylamine at $60{ }^{\circ} \mathrm{C}$ caused the release of $\sim 80 \%$ of the spore DPA after $80 \mathrm{~min}$ (Fig. 3), although no DPA was released upon incubation at $60{ }^{\circ} \mathrm{C}$ in buffer alone (data not shown). However, Pitt301 spores incubated with dodecylamine released DPA approximately fourfold faster than did JIR8094 spores (Fig. 3), similar to that which was seen with $\mathrm{KCl}$-induced germination (Fig. 2c).

\section{Germination by exogenous Ca-DPA}

Previous work has shown that B. subtilis spores can also germinate in the presence of exogenous Ca-DPA, which acts to promote cortex hydrolysis by activation of the CLE CwlJ (Paidhungat et al., 2001). Similar, albeit not identical, CLEs have been identified in other endospore-forming species (Foster \& Johnstone, 1987; Ishikawa et al., 1998; Makino et al., 1994; Miyata et al., 1995, 1997; Shimamoto et al., 2001), and bioinformatic analyses reveal that similar CLEs are also present in C. difficile (Sebaihia et al., 2006). When spores of strains JIR8094 and Pitt301 without prior heat activation were incubated with Ca-DPA and germination was measured, there were no significant changes in $\mathrm{OD}_{600}$ or spore refractility, and no release of DPA (data not shown). This is in agreement with the lack of effect of Ca-DPA on $C$. perfringens spores that have not been heat activated (Paredes-Sabja et al., 2008c). However, as described in Methods, within $60 \mathrm{~min}$ heat-activated JIR8094 and Pitt301 spores germinated $\geqslant 80 \%$ with $\mathrm{Ca}-$ DPA, as measured by both $\mathrm{OD}_{600}$ decrease and loss of DPA (data not shown). These results were confirmed by phasecontrast microscopy, as $\sim 80 \%$ of JIR8094 and Pitt301 spores became phase dark after 60 min incubation with Ca-DPA (data not shown). Heat-activated spores of $C$.

Table 3. Germination of $C$. difficile spores in different buffers

Heat-activated $\left(80{ }^{\circ} \mathrm{C}, 10 \mathrm{~min}\right.$ ) spores were incubated in $25 \mathrm{mM}$ buffer at $40{ }^{\circ} \mathrm{C}$ for $60 \mathrm{~min}$; the $\mathrm{OD}_{600}$ of the germinating cultures was measured and expressed as the percentage germination as described in Methods, and the approximate degree of spore germination was confirmed by phasecontrast microscopy. Results are means of duplicate experiments, and the variance in all cases was less than $10 \%$ of the mean.

\begin{tabular}{|c|c|c|c|c|c|c|c|c|}
\hline \multirow[t]{3}{*}{ Strain } & \multicolumn{8}{|c|}{ Mean percentage germination in $60 \mathrm{~min}$ in: } \\
\hline & \multicolumn{4}{|c|}{ Sodium phosphate at $\mathrm{pH}$ : } & \multicolumn{2}{|c|}{ Sodium citrate at $\mathrm{pH}$ : } & \multicolumn{2}{|c|}{ MOPS at $\mathrm{pH}$ : } \\
\hline & 3 & 4 & 6 & 7 & 6 & 7 & 6 & 7 \\
\hline JIR8094 & 15 & 17 & 40 & 31 & 20 & 26 & 18 & 17 \\
\hline Pitt33 & 22 & 25 & 80 & 17 & 31 & 17 & 9 & 8 \\
\hline Pitt40 & 14 & 17 & 25 & 20 & 17 & 20 & 6 & 15 \\
\hline Pitt221 & 12 & 20 & 15 & 11 & 11 & 14 & 3 & 9 \\
\hline Pitt251 & 28 & 26 & 40 & 17 & 15 & 15 & 14 & 14 \\
\hline Pitt301 & 22 & 26 & 60 & 26 & 34 & 23 & 23 & 28 \\
\hline
\end{tabular}




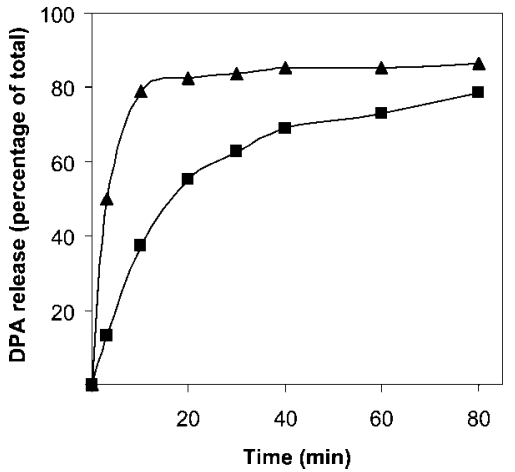

Fig. 3. Germination of spores of C. difficile strains with

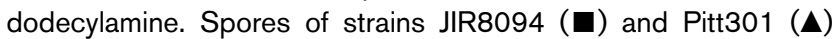
were incubated with dodecylamine and their germination was assessed by measuring DPA release, as described in Methods.

perfringens also germinate with Ca-DPA (Paredes-Sabja et al., 2008c).

\section{Bioinformatic analyses of C. difficile germination apparatus}

Although no homologue of the gerA family of operons that encode nutrient germinant receptors is present in the genome of C. difficile 630 (Sebaihia et al., 2006), C. difficile spores must have some way to sense when conditions are appropriate for the spores to germinate. Indeed, current and previous studies (Sorg \& Sonenshein, 2008; Wilson et al., 1982; Wilson, 1983) have shown that spores of various $C$. difficile strains are able to initiate germination in response to individual compounds. However, how these compounds are sensed is not clear; perhaps they directly activate CLEs or the release of Ca-DPA.

While genes encoding nutrient germinant receptors appear to be absent from the $C$. difficile 630 genome, genes encoding CLEs and SpoVA orthologues are present (Sebaihia et al., 2006), with the SpoVA proteins possibly involved in DPA release during spore germination and in DPA uptake during sporulation (Vepachedu \& Setlow 2007). The spoVA locus in $C$. difficile consists of three ORFs, CD0773, CD0774 and CD0775, and the organization of the $C$. difficile spoVA operon resembles that of $C$. perfringens with the order spoVAC, spoVAD and spoVAE (Myers et al., 2006; Sebaihia et al., 2006). Three CLE orthologues are encoded in the $C$. difficile genome. $C$. difficile ORF CD0551 encodes a 423-residue protein with high similarity $(67 \%)$ to a $C$. perfringens CLE, SleC, that is suggested to cause local changes in the structure of cortical PG through its lytic transglycosylase and $\mathrm{N}$-acetylmuramyl-L-alanine amidase activity (Kumazawa et al., 2007). CD0552 is annotated as sleB and encodes a 238-residue protein, but shares no similarity with CLEs from $C$. perfringens and B. subtilis. The third potential CLE in C. difficile is ORF CD3563, which encodes a 168-residue protein with $70 \%$ similarity to $B$. subtilis sleB.

\section{DISCUSSION}

CDAD is thought to be initiated by the ingestion of $C$. difficile spores, which then germinate, grow and produce virulence factors that cause severe damage to the intestinal epithelium, leading to an acute inflammatory response (Borriello, 1998; Hurley \& Nguyen, 2002). To understand the initial stages of pathogenesis of CDAD, we have characterized the germination of five CDAD isolates (McEllistrem et al., 2005) and one laboratory strain of $C$. difficile. Probably the most notable finding in this work is the identification of compounds that can induce the germination of $C$. difficile spores, since the identity of such compounds has long been controversial. The germination of spores of $C$. difficile by potassium salts alone was somewhat unexpected, but by no means unique, since spores of some $C$. perfringens and B. megaterium strains (Ando, 1974; Christie \& Lowe, 2007; Paredes-Sabja et al., 2008c; Rode \& Foster, 1962) germinate well with KI, KBr and $\mathrm{KCl} . \mathrm{K}^{+}$ions are also essential for the AGFK-initiated germination of B. subtilis spores (Setlow, 2003). The precise mechanism of spore germination by $\mathrm{K}^{+}$ions alone is not known, but in $B$. megaterium spores this appears likely to be via the activation of one or more of the spore nutrient germinant receptors (Christie \& Lowe, 2007; Cortezzo et al., 2004; Rode \& Foster, 1962), and this also appears to be the case, at least in part, for $C$. perfringens spores (ParedesSabja et al., 2008c). This cannot be the case for $C$. difficile spores, since at least strain JIR8094, a derivative of the sequenced strain 630 (Sebaihia et al., 2006), also appears to lack the nutrient germinant receptors that are orthologues of the GerA family of proteins, and thus $\mathrm{K}^{+}$ions may trigger germination of these spores by either activating a CLE or triggering Ca-DPA release directly. In addition, based on their germination phenotype, the spores from CDAD outbreak isolates also appear to lack the GerA family of proteins, and the variability observed might be due to differences in the number of downstream effectors of spore germination, such as SpoVA proteins or CLEs. These findings differ from those of earlier studies (Nakamura et al., 1985; Wilcox et al., 2000) that used lysozyme to enhance $C$. difficile spore germination and recovery. This enzyme bypasses the whole germination apparatus and degrades the PG cortex directly, allowing spore outgrowth, and is able to recover spores with an intact or even a damaged germination apparatus, as well as spores that have not been subjected to proper heat activation. However, it is possible that the triggering of C. difficile spore germination by $\mathrm{K}^{+}$ions is relevant to the ability of these spores to cause CDAD. The concentration of $\mathrm{K}^{+}$ions in the human GI tract increases from $\sim 10 \mathrm{mM}$ in the ileum to $\sim 75 \mathrm{mM}$ in the colon (Johnson, 2000). Thus, while the colon is low in nutrients, the concentration of $\mathrm{K}^{+}$ions is certainly more than high enough to induce 
germination of $C$. difficile spores, although the activation factors necessary for the germination of $C$. difficile spores in the gut are not known. The germination of $C$. difficile spores seen with BHI broth may also be due, at least in part, to $\mathrm{P}_{\mathrm{i}}\left(\geqslant 18 \mathrm{mM}\right.$ in BHI broth) and to the $\mathrm{K}^{+}$ions present in this medium, since the levels of $\mathrm{K}^{+}$ions are likely significant. Levels of $\mathrm{K}^{+}$ions and $\mathrm{P}_{\mathrm{i}}$ are also significant in meat products $(50-80$ and $42-60 \mathrm{mM}$, respectively) (USDA; http://www.nal.usda.gov/fnic/foodcomp/search/), so there could be significant spore germination in foods that are held for significant periods at temperatures that allow germination. However, we have not studied the $\mathrm{K}^{+}$- and $\mathrm{P}_{\mathrm{i}}$-dependent germination of $C$. difficile spores at different temperatures, and the temperature at which foods are held could greatly influence $\mathrm{K}^{+}$and $\mathrm{P}_{\mathrm{i}}$-dependent $C$. difficile spore germination.

A novel and unexpected finding in this work was that $C$. difficile spores germinated well at $\mathrm{pH} 6$ with $\mathrm{P}_{\mathrm{i}}$ alone. To our knowledge, $\mathrm{P}_{\mathrm{i}}$ has not been reported to induce germination of bacterial spores, although $\mathrm{P}_{\mathrm{i}}$ at $\mathrm{pH}$ 5.56.7 induces sporulation of $C$. perfringens (Philippe et al., 2006). The precise mechanism of initiation of $C$. difficile spore germination by $\mathrm{P}_{\mathrm{i}}$ is not known. However, again this might be advantageous for $C$. difficile spores in at least one of their natural habitats. The $\mathrm{pH}$ in the first centimetre of the duodenum is $2.0-3.5$, and gradually increases due to secretion of bicarbonate, reaching $\mathrm{pH}$ 5.0-6.0 near the mid-duodenum (Rune, 1973), where $P_{i}$ could trigger germination of $C$. difficile spores. $\mathrm{P}_{\mathrm{i}}$ is ubiquitous in the diet of healthy Western adults, and is present in the human intestinal lumen at 15-30 mM (Lemann, 1993; Walton \& Gray, 1979). As shown in this work, this $P_{i}$ concentration will induce germination of $C$. difficile spores.

One major conclusion from the identification of $\mathrm{K}^{+}$ions and $\mathrm{P}_{\mathrm{i}}$ as effective germinants for $C$. difficile spores is that ingested spores that survive stomach acidity (Jump et al., 2007) could germinate in any of three different segments of the GI tract: (1) the early duodenum, where the $\mathrm{pH}$ is $\sim 6.0$; (2) the small intestine, triggered by unidentified compounds, perhaps bile salts; and (3) the colon, where high levels of $\mathrm{K}^{+}$would trigger germination of the remaining dormant spores. However, CDAD symptoms affect primarily the large intestine and rarely the small intestine (Hurley \& Nguyen, 2002), perhaps because either most $C$. difficile spores germinate primarily in the large intestine due to the presence of $\mathrm{K}^{+}$ions or spores do germinate in early segments of the GI tract but do not outgrow appreciably in the small intestine and only outgrow, colonize, release toxins (TcdA and $\mathrm{TcdB}$ ) and cause CDAD symptoms in the large intestine.

Clearly, a significant unresolved paradox about the major findings in this work is how $C$. difficile spores respond to and initiate germination with $\mathrm{K}^{+}$ions and $\mathrm{P}_{\mathrm{i}}$ in the apparent absence of the receptors that recognize specific germinants. One possible explanation is that $\mathrm{K}^{+}$ions and $\mathrm{P}_{\mathrm{i}}$ directly activate a CLE and/or Ca-DPA release. Ongoing work is thus oriented towards investigating the roles played by a number of proteins, including CLEs that may be involved in cortex PG hydrolysis (Foster \& Johnstone, 1987; Ishikawa et al., 1998; Makino et al., 1994; Miyata et al., 1995, 1997; Shimamoto et al., 2001) and SpoVA proteins implicated in Ca-DPA release (Paredes-Sabja et al., 2008b), in the germination of $C$. difficile spores with $\mathrm{K}^{+}$ and $\mathrm{P}_{\mathrm{i}}$. The resolution of the paradox noted above as well as a more thorough understanding of the germination of $C$. difficile spores may well have applications in the areas of public health and food safety.

\section{ACKNOWLEDGEMENTS}

This research was supported by a grant from the N. L. Tartar Foundation of Oregon State University to M.R.S., and by a grant from the Army Research Office to M.R.S. and P.S. D.P.-S. was supported by a fellowship from MIDEPLAN (CHILE).

\section{REFERENCES}

Ando, Y. (1974). Ionic germination of spores of Clostridium perfringens type A. Jpn J Microbiol 18, 433-439.

Bartlett, J. G. (1992). Antibiotic-associated diarrhea. Clin Infect Dis 15, 573-581.

Bean, N. H., Griffin, P. M., Goulding, J. S. \& Ivey, C. B. (1990). Foodborne disease outbreaks, 5-year summary, 1983-1987. MMWR CDC Surveill Summ 39, 15-57.

Borriello, S. P. (1998). Pathogenesis of Clostridium difficile infection. J Antimicrob Chemother 41 (Suppl. C), 13-19.

Borriello, S. P., Davies, H. A., Kamiya, S., Reed, P. J. \& Seddon, S. (1990). Virulence factors of Clostridium difficile. Rev Infect Dis 12 (Suppl. 2), S185-S191.

Broussolle, V., Alberto, F., Shearman, C. A., Mason, D. R., Botella, L., Nguyen-The, C., Peck, M. W. \& Carlin, F. (2002). Molecular and physiological characterization of spore germination in Clostridium botulinum and C. sporogenes. Anaerobe 8, 89-100.

Cabrera-Martinez, R. M., Tovar-Rojo, F., Vepachedu, V. R. \& Setlow, P. (2003). Effects of overexpression of nutrient receptors on germination of spores of Bacillus subtilis. J Bacteriol 185, 2457-2464.

Christie, G. \& Lowe, C. R. (2007). Role of chromosomal and plasmidborne receptor homologues in the response of Bacillus megaterium QM B1551 spores to germinants. J Bacteriol 189, 4375-4383.

Clements, M. O. \& Moir, A. (1998). Role of the gerI operon of Bacillus cereus 569 in the response of spores to germinants. J Bacteriol 180, 6729-6735.

Cortezzo, D. E., Setlow, B. \& Setlow, P. (2004). Analysis of the action of compounds that inhibit the germination of spores of Bacillus species. J Appl Microbiol 96, 725-741.

Cowan, A. E., Koppel, D. E., Setlow, B. \& Setlow, P. (2003). A soluble protein is immobile in dormant spores of Bacillus subtilis but is mobile in germinated spores: implications for spore dormancy. Proc Natl Acad Sci U S A 100, 4209-4214.

Duncan, C. L. \& Strong, D. H. (1968). Improved medium for sporulation of Clostridium perfringens. Appl Microbiol 16, 82-89.

Foster, S. J. \& Johnstone, K. (1987). Purification and properties of a germination-specific cortex-lytic enzyme from spores of Bacillus megaterium KM. Biochem J 242, 573-579. 
Hurley, B. W. \& Nguyen, C. C. (2002). The spectrum of pseudomembranous enterocolitis and antibiotic-associated diarrhea. Arch Intern Med 162, 2177-2184.

Ishikawa, S., Yamane, K. \& Sekiguchi, J. (1998). Regulation and characterization of a newly deduced cell wall hydrolase gene $(c w l J)$ which affects germination of Bacillus subtilis spores. J Bacteriol 180, 1375-1380.

Johnson, L. R. (2000). Gastrointestinal Physiology, 6th edn. St Louis, MO: Mosby, Inc.

Johnson, S., Clabots, C. R., Linn, F. V., Olson, M. M., Peterson, L. R. \& Gerding, D. N. (1990). Nosocomial Clostridium difficile colonisation and disease. Lancet 336, 97-100.

Jump, R. L., Pultz, M. J. \& Donskey, C. J. (2007). Vegetative Clostridium difficile survives in room air on moist surfaces and in gastric contents with reduced acidity: a potential mechanism to explain the association between proton pump inhibitors and $C$. difficile-associated diarrhea? Antimicrob Agents Chemother 51, 2883 2887.

Kelly, C. P. \& LaMontt, J. T. (1998). Clostridium difficile infection. Annu Rev Med 49, 375-390.

Kelly, C. P., Pothoulakis, C. \& LaMont, J. T. (1994). Clostridium difficile colitis. N Engl J Med 330, 257-262.

Kokai-Kun, J. F., Songer, J. G., Czeczulin, J. R., Chen, F. \& McClane, B. A. (1994). Comparison of Western immunoblots and gene detection assays for identification of potentially enterotoxigenic isolates of Clostridium perfringens. J Clin Microbiol 32, 2533-2539.

Kumazawa, T., Masayama, A., Fukuoka, S., Makino, S., Yoshimura, T. \& Moriyama, R. (2007). Mode of action of a germination-specific cortex-lytic enzyme, SleC, of Clostridium perfringens S40. Biosci Biotechnol Biochem 71, 884-892.

Kyne, L., Hamel, M. B., Polavaram, R. \& Kelly, C. P. (2002). Health care costs and mortality associated with nosocomial diarrhea due to Clostridium difficile. Clin Infect Dis 34, 346-353.

Lemann, J. (1993). Intestinal absorption of calcium, magnesium, and phosphorus. In Primer on the Metabolic Bone Diseases and Disorders of Mineral Metabolism, pp. 46-50. Edited by M. J. Favus. New York: The American Society for Bone and Mineral Research.

Makino, S., Ito, N., Inoue, T., Miyata, S. \& Moriyama, R. (1994). A spore-lytic enzyme released from Bacillus cereus spores during germination. Microbiology 140, 1403-1410.

McEllistrem, M. C., Carman, R. J., Gerding, D. N., Genheimer, C. W. \& Zheng, L. (2005). A hospital outbreak of Clostridium difficile disease associated with isolates carrying binary toxin genes. Clin Infect Dis $\mathbf{4 0}$, 265-272.

McFarland, L. V., Mulligan, M. E., Kwok, R. Y. \& Stamm, W. E. (1989). Nosocomial acquisition of Clostridium difficile infection. N Engl J Med 320, 204-210.

Miyata, S., Moriyama, R., Sugimoto, K. \& Makino, S. (1995). Purification and partial characterization of a spore cortex-lytic enzyme of Clostridium perfringens S40 spores. Biosci Biotechnol Biochem 59, 514-515.

Miyata, S., Kozuka, S., Yasuda, Y., Chen, Y., Moriyama, R., Tochikubo, K. \& Makino, S. (1997). Localization of germination-specific spore-lytic enzymes in Clostridium perfringens S40 spores detected by immunoelectron microscopy. FEMS Microbiol Lett 152, 243-247.

Moir, A., Corfe, B. M. \& Behravan, J. (2002). Spore germination. Cell Mol Life Sci 59, 403-409.

Myers, G. S., Rasko, D. A., Cheung, J. K., Ravel, J., Seshadri, R., DeBoy, R. T., Ren, Q., Varga, J., Awad, M. M. \& other authors (2006). Skewed genomic variability in strains of the toxigenic bacterial pathogen, Clostridium perfringens. Genome Res 16, 1031-1040.
Nakamura, S., Yamakawa, K., Izumi, J., Nakashio, S. \& Nishida, S. (1985). Germinability and heat resistance of spores of Clostridium difficile strains. Microbiol Immunol 29, 113-118.

O'Connor, J. R., Lyras, D., Farrow, K. A., Adams, V., Powell, D. R., Hinds, J., Cheung, J. K. \& Rood, J. I. (2006). Construction and analysis of chromosomal Clostridium difficile mutants. Mol Microbiol 61, 1335-1351.

Paidhungat, M. \& Setlow, P. (2000). Role of ger proteins in nutrient and nonnutrient triggering of spore germination in Bacillus subtilis. J Bacteriol 182, 2513-2519.

Paidhungat, M., Setlow, B., Driks, A. \& Setlow, P. (2000). Characterization of spores of Bacillus subtilis which lack dipicolinic acid. J Bacteriol 182, 5505-5512.

Paidhungat, M., Ragkousi, K. \& Setlow, P. (2001). Genetic requirements for induction of germination of spores of Bacillus subtilis by $\mathrm{Ca}^{2+}$-dipicolinate. J Bacteriol 183, 4886-4893.

Paidhungat, M., Setlow, B., Daniels, W. B., Hoover, D., Papafragkou, E. \& Setlow, P. (2002). Mechanisms of induction of germination of Bacillus subtilis spores by high pressure. Appl Environ Microbiol 68, 3172-3175.

Paredes-Sabja, D., Sarker, N., Setlow, B., Setlow, P. \& Sarker, M. R. (2008a). Roles of DacB and Spm proteins in Clostridium perfringens spore resistance to moist heat, chemicals and UV radiation. Appl Environ Microbiol 74, 3730-3738.

Paredes-Sabja, D., Setlow, B., Setlow, P. \& Sarker, M. R. (2008b). Characterization of Clostridium perfringens spores that lack SpoVA proteins and dipicolinic acid. J Bacteriol 190, 4648-4659.

Paredes-Sabja, D., Torres, J. A., Setlow, P. \& Sarker, M. R. (2008c). Clostridium perfringens spore germination: characterization of germinants and their receptors. J Bacteriol 190, 1190-1201.

Philippe, V. A., Mendez, M. B., Huang, I. H., Orsaria, L. M., Sarker, M. R. \& Grau, R. R. (2006). Inorganic phosphate induces spore morphogenesis and enterotoxin production in the intestinal pathogen Clostridium perfringens. Infect Immun 74, 3651-3656.

Rode, L. J. \& Foster, J. W. (1962). Ionic germination of spores of Bacillus megaterium QM B 1551. Arch Mikrobiol 43, 183-200.

Rotman, Y. \& Fields, M. L. (1968). A modified reagent for dipicolinic acid analysis. Anal Biochem 22, 168.

Rune, S. J. (1973). pH in the human duodenum. Its physiological and pathophysiological significance. Digestion 8, 261-268.

Sebaihia, M., Wren, B. W., Mullany, P., Fairweather, N. F., Minton, N., Stabler, R., Thomson, N. R., Roberts, A. P., Cerdeño-Tárraga, A. M. \& other authors (2006). The multidrug-resistant human pathogen Clostridium difficile has a highly mobile, mosaic genome. Nat Genet 38, 779-786.

Setlow, P. (2003). Spore germination. Curr Opin Microbiol 6, 550-556.

Setlow, P. (2006). Spores of Bacillus subtilis: their resistance to and killing by radiation, heat and chemicals. J Appl Microbiol 101, 514-525.

Setlow, B., Cowan, A. E. \& Setlow, P. (2003). Germination of spores of Bacillus subtilis with dodecylamine. J Appl Microbiol 95, 637-648.

Shimamoto, S., Moriyama, R., Sugimoto, K., Miyata, S. \& Makino, S. (2001). Partial characterization of an enzyme fraction with protease activity which converts the spore peptidoglycan hydrolase (SleC) precursor to an active enzyme during germination of Clostridium perfringens S40 spores and analysis of a gene cluster involved in the activity. J Bacteriol 183, 3742-3751.

Sorg, J. A. \& Sonenshein, A. L. (2008). Bile salts and glycine as cogerminants for Clostridium difficile spores. J Bacteriol 190, 2505-2512. 
Vepachedu, V. R. \& Setlow, P. (2005). Localization of SpoVAD to the inner membrane of spores of Bacillus subtilis. J Bacteriol 187, 5677-5682.

Vepachedu, V. R. \& Setlow, P. (2007). Role of SpoVA proteins in release of dipicolinic acid during germination of Bacillus subtilis spores triggered by dodecylamine or lysozyme. J Bacteriol 189, 1565-1572.

Voth, D. E. \& Ballard, J. D. (2005). Clostridium difficile toxins: mechanism of action and role in disease. Clin Microbiol Rev 18, 247-263.

Walton, J. \& Gray, T. K. (1979). Absorption of inorganic phosphate in the human small intestine. Clin Sci (Lond) 56, 407-412.
Wilcox, M. H., Fawley, W. N. \& Parnell, P. (2000). Value of lysozyme agar incorporation and alkaline thioglycollate exposure for the environmental recovery of Clostridium difficile. J Hosp Infect 44, 65-69.

Wilson, K. H. (1983). Efficiency of various bile salt preparations for stimulation of Clostridium difficile spore germination. J Clin Microbiol 18, 1017-1019.

Wilson, K. H., Kennedy, M. J. \& Fekety, F. R. (1982). Use of sodium taurocholate to enhance spore recovery on a medium selective for Clostridium difficile. J Clin Microbiol 15, 443-446.

Edited by: T. Abee 